${ }^{\bullet}$ Entomologica Fennica. 30 October 2002

\title{
Three new species of Scythrididae from central Turkey (Lepidoptera: Scythrididae)
}

\author{
Jari Junnilainen
}

Junnilainen, J. 2002: Three new species of Scythrididae from central Turkey (Lepidoptera: Scythrididae). — Entomol. Fennica 13: 146-152.

Three new species of Scythrididae are described, viz. Scythris alceella sp. n., S. lagomorphella sp. n. and S. tabelli sp. n., on the basis of material collected from the central Turkey, where they occur in open highland habitats. Another unknown species is described but left unnamed due to the paucity of material.

Jari Junnilainen, Mahlapolku 3, FIN-01730 Vantaa, Finland; E-mail: junnilainen@fi.ibm.com

Received 28 February 2001, accepted 7 May 2002

\section{Introduction}

The scythridid fauna of Turkey is still rather poorly studied and a profound study has not yet been published, although Otto Staudinger's publication on a trip to Amasia in 1875 embraced several new species (Staudinger 1880). Bengtsson (1997a) presented additional data. The author has collected a large number of Scythrididae during the summer 1999 in two areas that are located in central Turkey, and describes new species found during these trips. The collecting areas were in highlands above $900 \mathrm{~m}$ a.s.l., and in mountains up to $3917 \mathrm{~m}$ a.s.l. One of the localities lies at the small village of Cetince, not far from Aksehir situated on the southern side of Sultan Daglari mountain range. The habitats are xerothermic, mainly agricultural sites including spots of interesting primary slopes with calcareous soil and diverse vegetation. The second locality is located in the neighbourhood of Ürgüp not far from Kayseri. The habitats are dry, open, sandy areas partly with limestone but also with pastures and fruit plantations, the low vegetation being usually sparse. The type specimens of the described species can be loaned by request through the Finnish $\mathrm{Mu}-$ seum of Natural History, the University of Helsinki or directly from the author.

\section{Scythris alceella sp. $\mathrm{n}$.}

Type material. Holotype: O' (Fig. 1): Turkey, Ürgüp, Mustafapasa, 21.VI.1999, leg. J. Junnilainen. Genitalia slide: J. Junnilainen prep. no. 00013102. Paratype: 1 ㅇ same data as holotype. Genitalia slide: J. Junnilainen prep. no. 00013101. In coll. J. Junnilainen.

Diagnosis. S. alceella is difficult to separate from other small unicoloured, dark scythridids based on its outer appearance alone. The antlershaped valvae are characteristic of the male genitalia, and similar features are not seen in any other known scythridid. Also the sterigma in the female genitalia forms a specific U-shaped profile.

Description. Wingspan $8.5-9.5 \mathrm{~mm}$. Head fuscous with whitish scales around eye. Haustellum and neck tuft whitish. Collar, tegula and thorax fuscous. Antenna dark brown. Labial palpus fuscous, except first segment and upper surface whitish. Legs basally whitish, toward tarsus fuscous. Abdomen dorsally dark fuscous, ventrally paler. Forewing and cilia fuscous, fold somewhat paler. Hindwing dark fuscous. Female similar to male.

Male genitalia (Fig. 2). Uncus broad subtrapezoid plate. Gnathos long and slender, bent, 


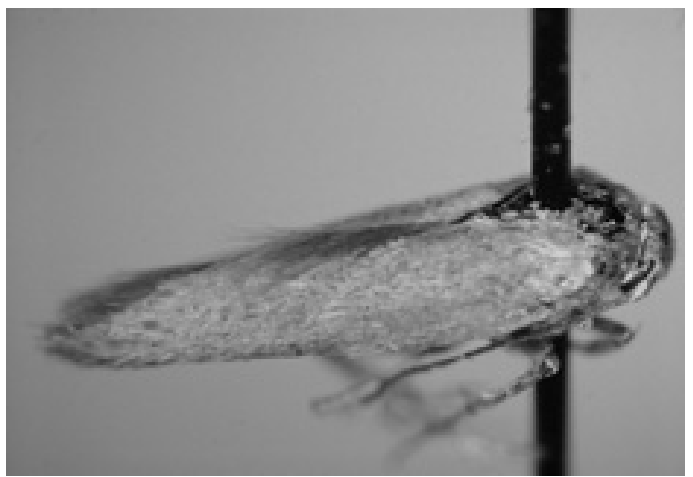

Fig. 1. Scythris alceella sp. n. ơ holotype.

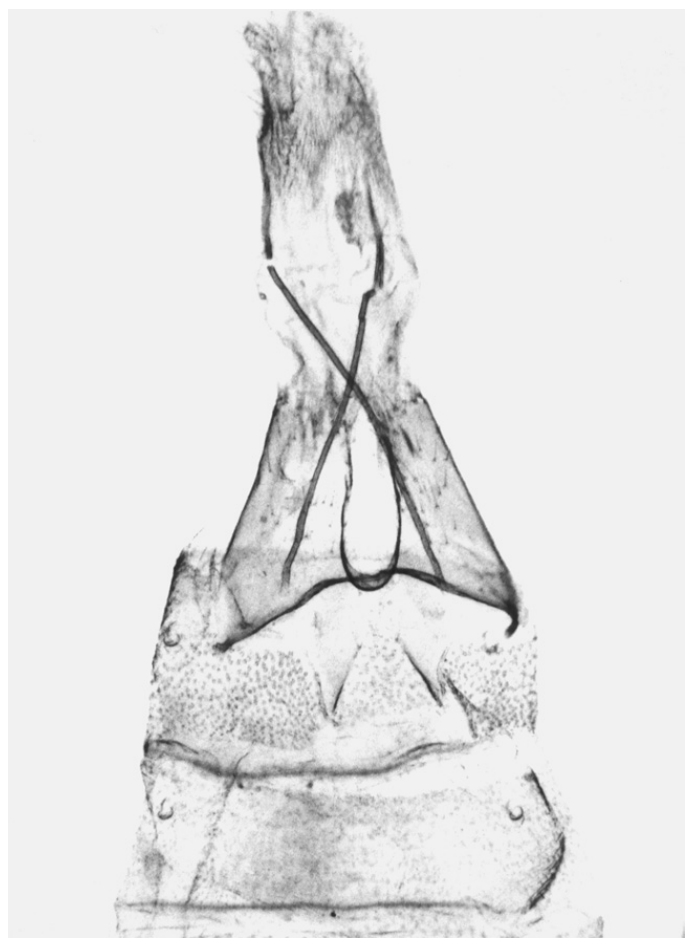

Fig. 3. Scythris alceella sp. n., o papillae anales and ostium bursae (paratype, Turkey Mustafapasa. Prep. no. 00013101/Junnilainen).

apically tapered. Valva large, antler-shaped, widening toward termen, terminal part with a pointed subtriangular extension dorsally, ventral margin basally concave, dorsal margin convex. Aedeagus as long as gnathos, tapering toward apex, distal half bent. Tergum VIII broad, posterior margin medially deeply indented, anterior margin medially extended. Sternum VIII arched, moderately

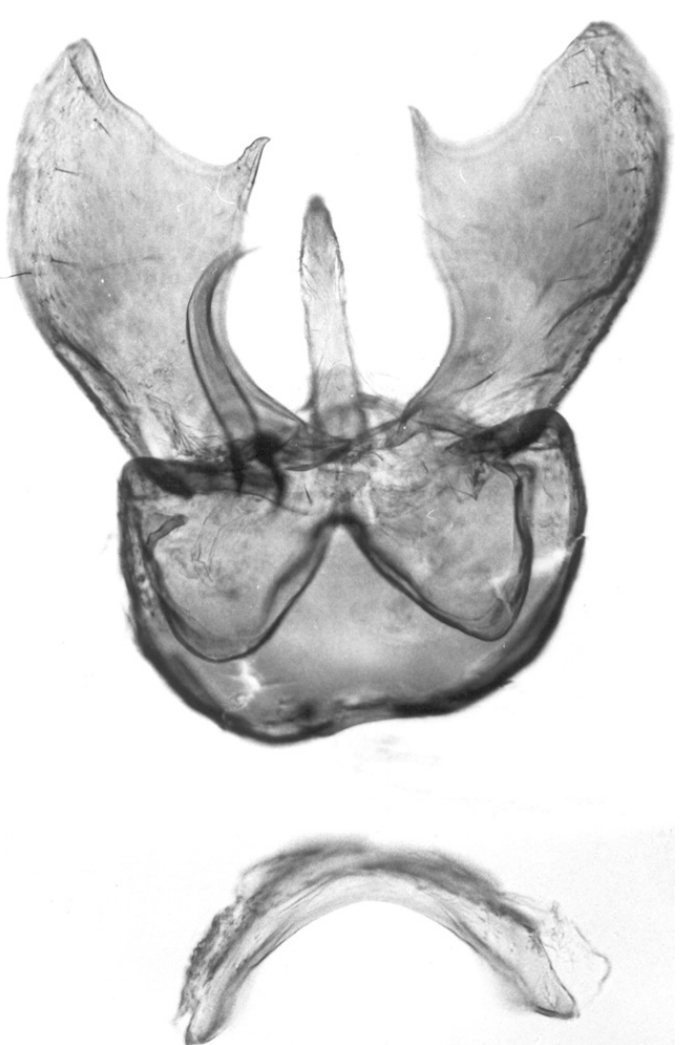

Fig. 2. Scythris alceella sp. n., ơ genitalia (holotype, Turkey Mustafapasa. Prep. no. 00013102/Junnilainen).

narrow plate (Sternum VIII separately and Tergum VIII under abdominal segment VII in Fig. 2).

Female genitalia (Fig. 3). Sterigma forming a deep, U-shaped indentation in the middle of segment VIII. Segment VII contains a pair of anteriorly acute-angle structures. Apophyses anteriores very short. Apophyses posteriores equal length as abdominal segments VII and VIII together.

Bionomy. The specimens were collected in the middle of June. The habitat was a sandy xerothermic place with sparse vegetation.

Distribution. Turkey. Only known from the type locality.

Etymology. Lat. Alces alces $=$ elk. Derived from the male genitalia construction, where the valvae are antler-shaped.

Remarks. Based on the genitalic morphology S. alceella cannot be assigned to any known species-group of Scythrididae. 


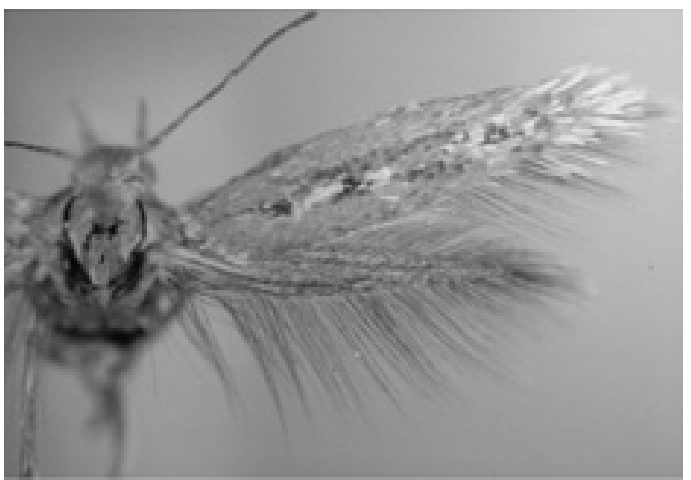

Fig. 4. Scythris sp. .

\section{Scythris sp.}

Material. 1 오 (Fig. 4): Turkey, Ürgüp 5 km NW, 17.VI.1999, J. Junnilainen leg. Genitalia slide: J. Junnilainen prep. no. 00013106. In coll. J. Junnilainen.

External appearance. Wingspan $8.0 \mathrm{~mm}$. Head, antenna, collar, tegula and thorax pale fuscous, scattered whitish scales around eye. Neck tuft, haustellum and labial palp whitish. Legs whitish, partly suffused with fuscous scales. Abdomen dorsally dark brown, ventrally paler. Forewing ground colour pale fuscous; disconnected white streak in basal part of fold, cut by two blackish brown spots at 0.2, 0.4; dark separate spot above tornus, apical part largely scattered paler scales. Hindwing fuscous.

Female genitalia (Fig. 5). Sterigma triangular, tip strongly sclerotized with distinct median cross section; anterior corners extended. Sternum VII subrectangular, posterior margin medially strongly extended. Apophyses posteriores somewhat equal length as abdominal segments VII and VIII together. Apophyses anteriores 3/5 length of apophyses posteriores.

Remarks. Habitually Scythris sp. most resembles $S$. albisaxella K. Nupponen \& T. Nupponen, 2000 (Nupponen et al. 2000). Also the details in the morphology of female genitalia, such as a triangular sterigma with strongly sclerotized tip and the shape of sternum VII, places Scythris sp into the same group as $S$. kullbergi Bengtsson, 1997 , S. terekholensis Bengtsson, 1997 and S. albisaxella. This taxon differs from those clearly by having a median cross section at the tip of sterigma as well as a specific shape of posterior mar-

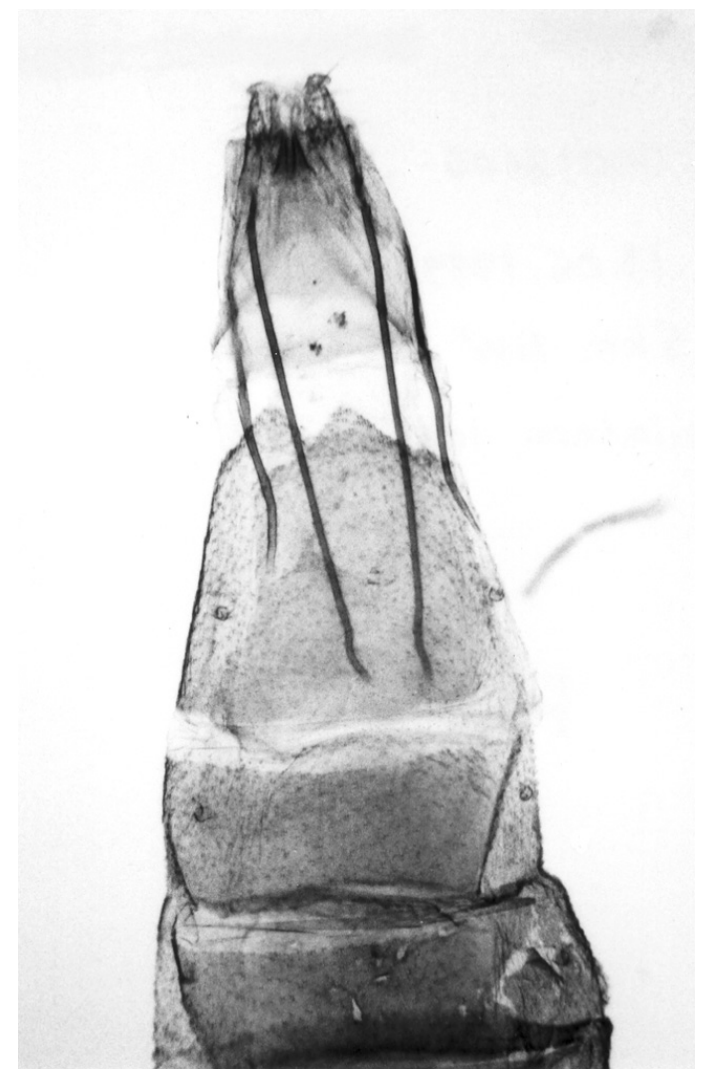

Fig. 5. Scythris sp., ㅇ papillae anales and ostium bursae (Turkey Urgüp. Prep. no. 00013106/ Junnilainen).

gin of sternum VII, which is medially extended without any incision or sclerotization. Also $S$. arkaimensis Bengtsson, 2000 and S. lagomorphella sp. n. (see below) belong to the same group on the basis of the similar male genitalia structure, having basally fused valvae and asymmetrical, strongly sclerotized gnathos as e.g. $S$. terekholensis and S. albisaxella (Nupponen et al. 2000). According to the original description (Nupponen et al. 2000), the only known specimen of $S$. arkaimensis is missing its gnathos, due to the genitalia of the specimen having been partly destroyed by noxious animals. However, there are two asymmetrical sclerotized processes, situated close to basal part of valva, that possibly belong to the gnathos. Although Scythris sp. does not fit any earlier known taxon, I leave the final description for the future when more material is available for study, including male specimens. 


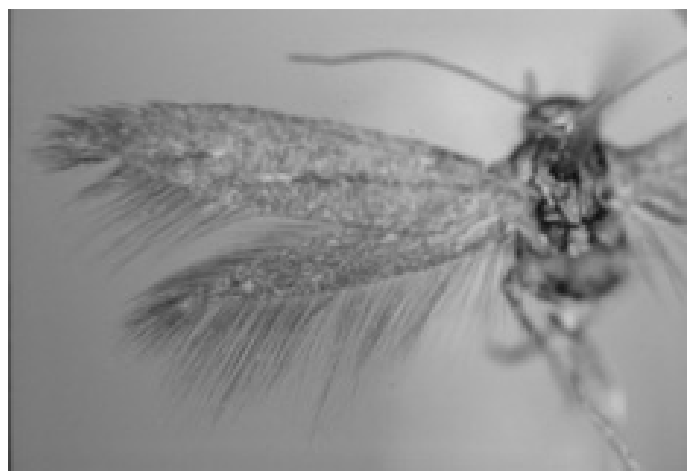

Fig. 6. Scythris lagomorphella sp. n. ơ holotype.

\section{Scythris lagomorphella sp. n.}

Type material. Holotype: O' (Fig. 6): Turkey, Aksehir 35 km SW, Cetince 1200 m, 15.VI.1999, J. Junnilainen leg. Genitalia slide: J. Junnilainen prep. no. 00013105. In coll. J. Junnilainen.

Diagnosis. S. lagomorphella sp. $\mathrm{n}$. is a very small unicolorous species, externally easily confused with many other small scythridids. The male genitalia construction indicates a close relationship to S. albisaxella K. Nupponen \& T. Nupponen, 2000 and S. arkaimensis Bengtsson, 2000, but $S$. lagomorphella sp. n. differs from these by a distally rounded and not bilobed tergum VIII, also shape of valva characteristically broadening toward a rounded apex.

Description. Wingspan $7.5 \mathrm{~mm}$. Head, antenna, labial palp, collar, tegula and thorax olive brown. Haustellum and neck tuft whitish, scattered whitish scales around eye. Forelegs and midlegs olive brown, hindlegs paler. Abdomen dorsally dark brown, ventrally paler. Forewing unicolorous, dark olive brown. Hindwing dark fuscous.

Male genitalia (Fig. 7). Tegumen roundish posteriorly asymmetrical, right side with strong basal arm of gnathos. Gnathos asymmetrical, bifurcate, anterior process stout, posterior process long and slender, both processes strongly sclerotized. Uncus roundish, situated on the left. Aedeagus thick and moderately long, distally tapered. Valvae symmetrical, setose, basally fused, elongate, rather narrow at base, broadening toward rounded apex. Sternum VIII subtrapezoid, posterior margin straight. Tergum VIII subtriangular, distally rounded; anterior margin con-

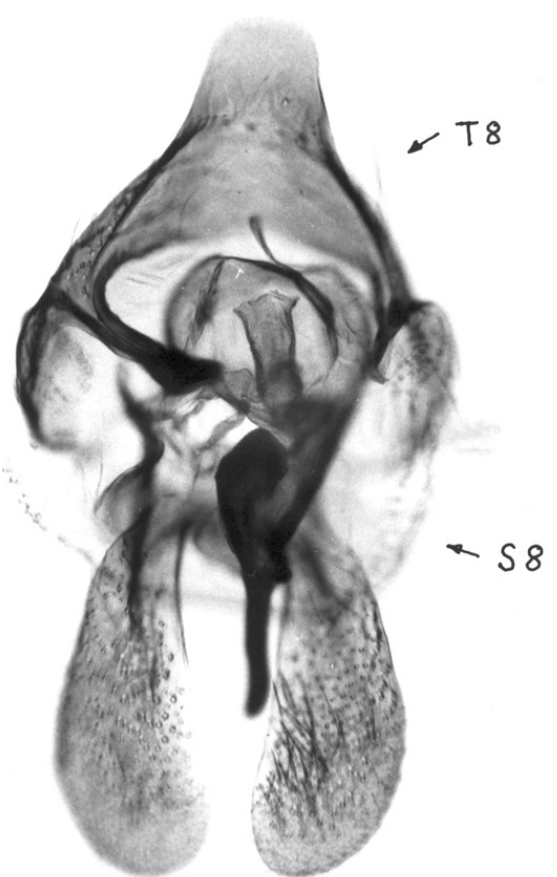

Fig. 7. Scythris lagomorphella sp. n., o genitalia (holotype, Turkey Cetince. Prep. no. 00013105/ Junnilainen).

cave, both lateral margins with asymmetrical process, larger one distally strongly sclerotized.

Female genitalia. Unknown.

Distribution. Turkey. Only known from the type locality.

Bionomy. The holotype was collected in the middle of June. The biotope was a calcareous eastern slope with diverse vegetation.

Etymology. Lat. Lagomorpha $=$ the order to which the hare belongs. Gr. lagos = hare. The species name is derived from the male genitalic structure, which is reminiscent of the head of a hare.

\section{Scythris tabelli sp. n.}

Type material. Holotype: Ơ (Fig. 8): Turkey, Aksehir 35 km SW, Cetince 1200 m, 14.VI.1999, leg. J. Junnilainen. In coll. J. Junnilainen. Para-

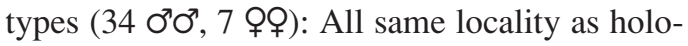

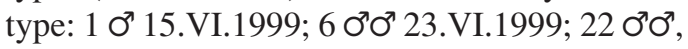
3우우 24.VI.1999; 5 రారా, 3 우우 25.VI.1999; 1 우 


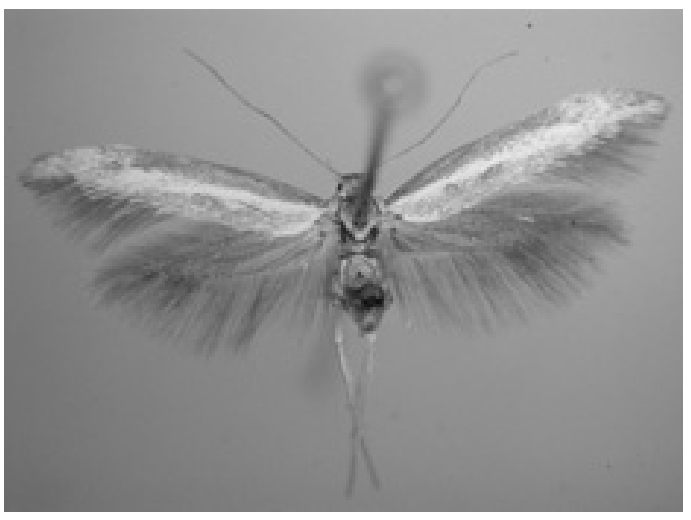

Fig. 8. Scythris tabelli sp. n. ơ holotype.

26.VI.1999. Genitalia slides: J. Junnilainen prep. no. 99110102, 99110103, 00021501, 00021502. In coll. J. Junnilainen.

Diagnosis. Externally S. tabelli sp. n. is difficult to separate from $S$. vartianae Kasy, 1962, S. dissimilella (Herrich-Schäffer, 1855), S. tenuivittella (Stainton, 1867), S. traugotti Bengtsson, 1991 and S. derrai Bengtsson, 1991. The male genitalia resemble to a great extent $S$. derrai. However, $S$. tabelli does not have laterally pointed processes in sternum VIII lobes, rather they are long and plump, symmetrically and strongly tapered at apex, also aedeagus is more winding, and arm of gnathos is longer and basally narrower. S. vittella (O. G. Costa, [1834]) also has partly similar genitalic structures, but it differs clearly by having a rather short and basally broad gnathos. In addition, the sternum VIII lobes in $S$. vittella are relatively short and laterally of about even thickness, posterior margin broad and blunt, even concave. The female genitalia is rather similar to those of $S$. vartianae and S. traugotti, but posterior half of ductus bursae is sclerotized and posterior quarter is sparsely wrinkled.

Description. Wingspan 12-15 mm. Head olive brown with whitish scales around eye. Haustellum and neck tuft whitish. Antenna and scape dark olive brown. Collar and tegula mingled with brown to almost whitish scales. Thorax olive brown. Labial palpus upcurved, whitish, mottled with olive brown scales. Legs whitish, fore- and midlegs partly scattered with fuscous scales. Abdomen olive brown, beneath paler. Forewing ground colour olive brown, fold covered with whitish scales, apical and dorsal part

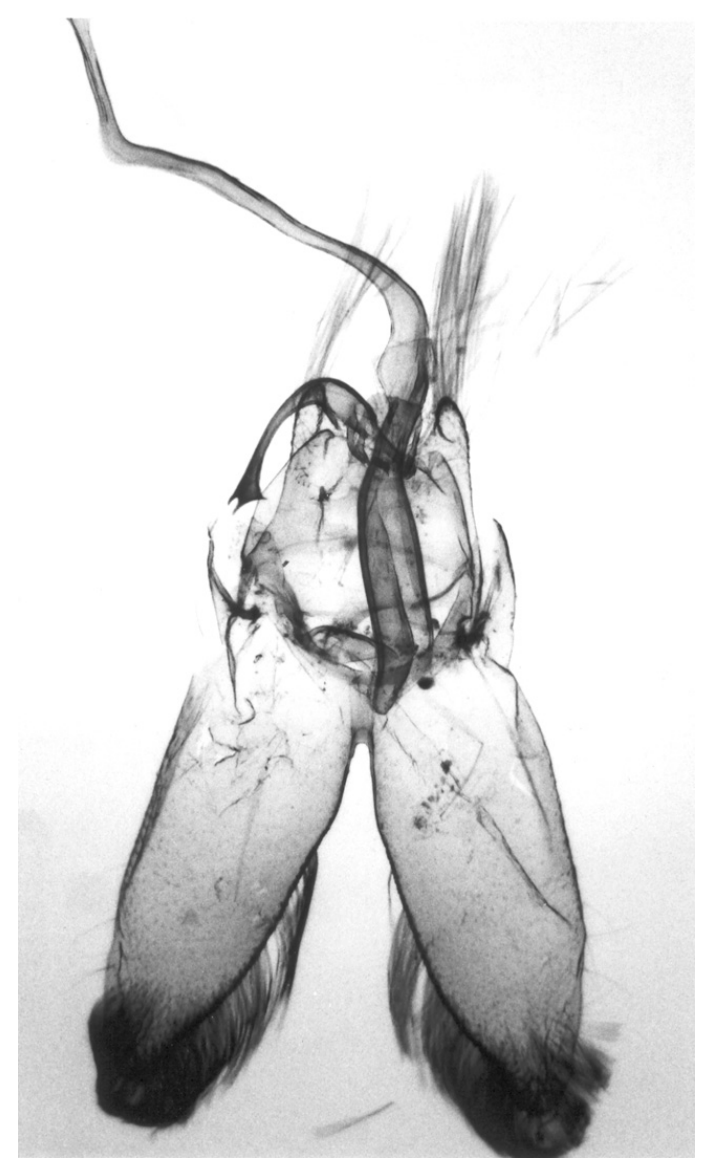

Fig. 9. Scythris tabelli sp. n., o" genitalia (paratype, Turkey Cetince. Prep. no. 99110102/Junnilainen).

often largely scattered with whitish scales, cilia fuscous. Hindwing fuscous.

Male genitalia (Figs. 9-10). Uncus a square plate. Gnathos relatively long and slender with three pointed spines at apex. Valva small, narrow and slightly curved at apex. Saccus as long as tegumen, rather broad, slightly tapered and backcurved anteriorly. Aedeagus as long as sternum VIII and tergum VIII together, basal part broad with two gentle loops, strongly curved at middle and apical part thin with strong loop. Tergum VIII subrectangular plate, anterior margin shallowly concave, posterior margin deeply concave. Sternum VIII bilobate, lobes long and plump, apically strongly tapered.

Female genitalia (Fig. 11). Sterigma weakly sclerotized, composed by a pair of weakly visible rhomboid-shaped plates (not visible in Fig. 11). 


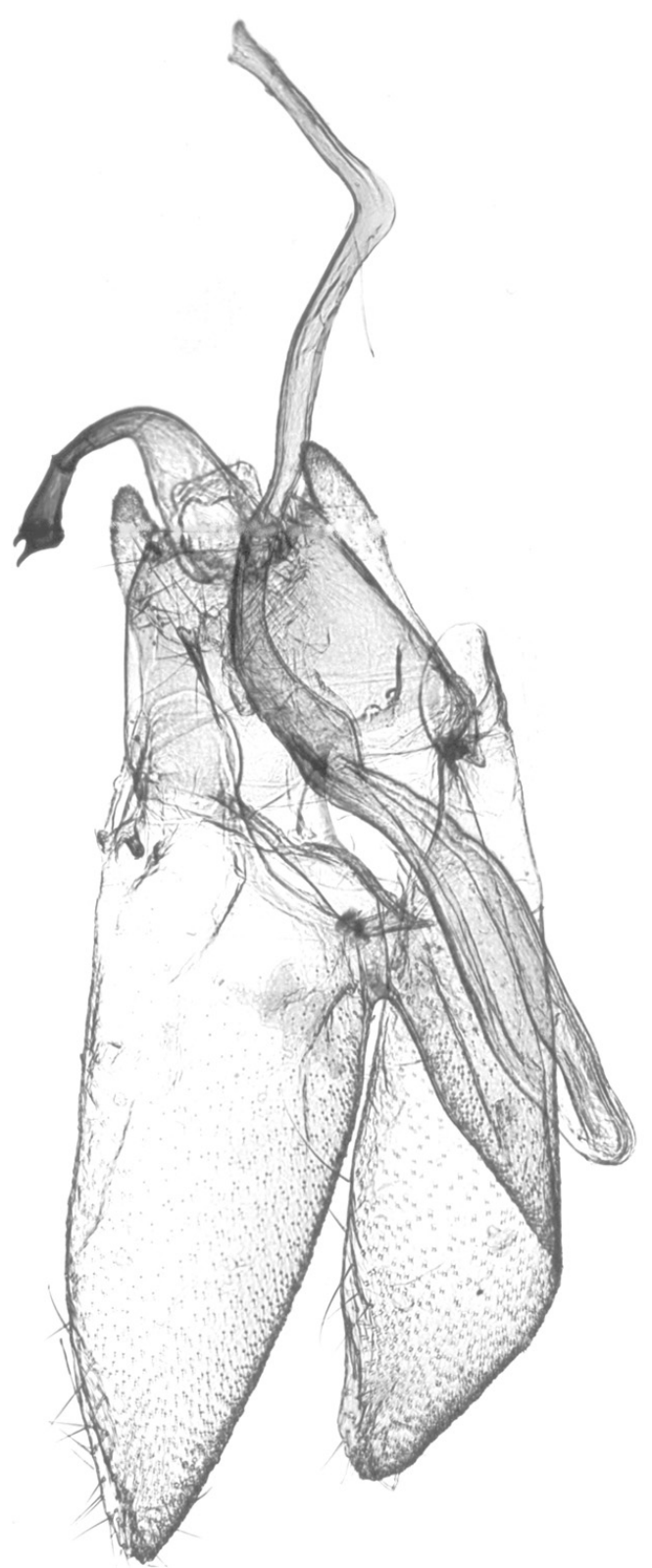

Fig. 10. Scythris tabelli sp.n., o' genitalia (paratype, Turkey Cetince. Prep. no. 00021502/Junnilainen).

Ductus bursae somewhat longer as segments VI and VII together, anterior half gradually widening toward ostium bursae; posterior half sclerotized, posterior quarter sparsely wrinkled. Posterior margin of segment VII with deep medial incision. Apophyses posteriores $2 \times$ length of apophyses anteriores.

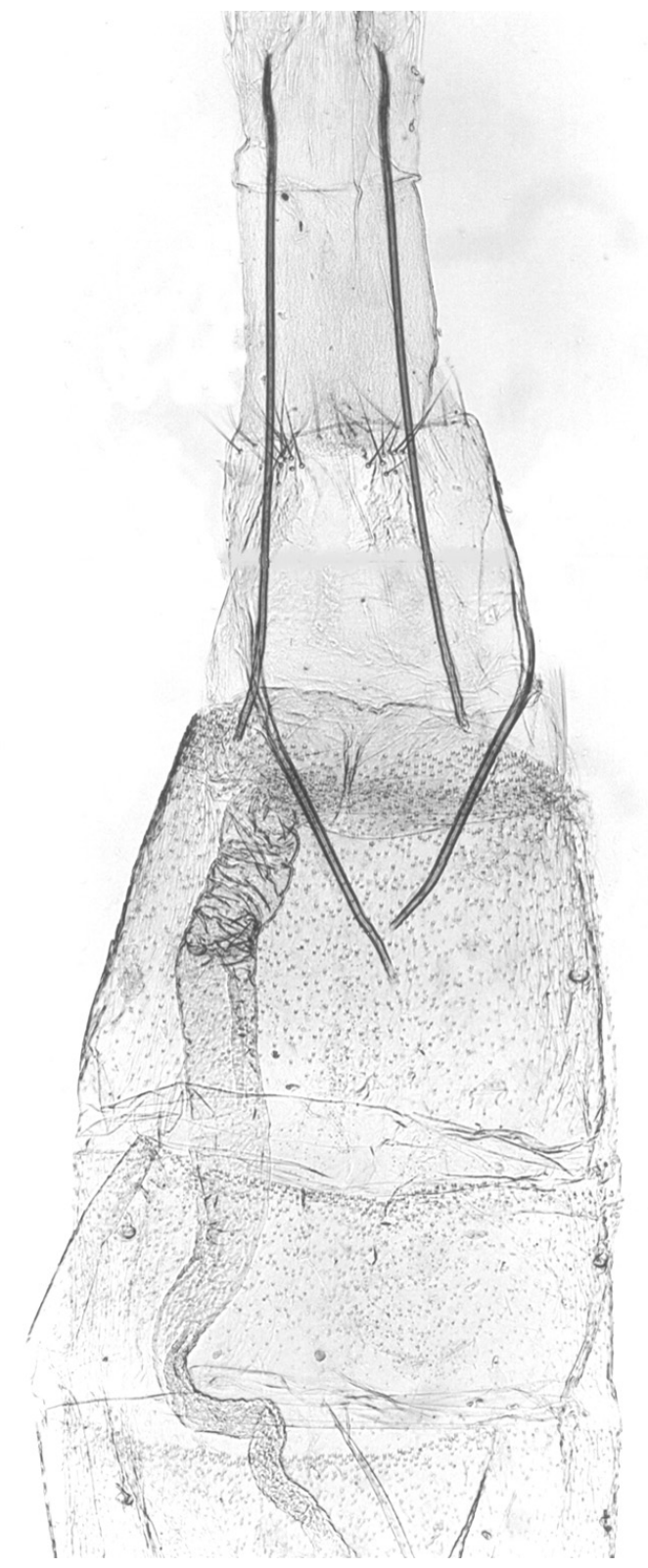

Fig. 11. Scythris tabelli sp. n., o papillae anales and ostium bursae (paratype, Turkey Cetince. Prep. no. 99110103/Junnilainen).

Bionomy. The type series was collected in the middle of June. The specimens were swarming late in the evening just before sunset and again early in the morning. The habitat was a calcareous eastern slope with rich flora.

Distribution. Only known from the type locality in Turkey. 
Etymology. Scythris tabelli sp. n. is dedicated to Jukka Tabell, Hartola, Finland, who was my companion on the expedition when the type series was collected.

Remarks. S. tabelli is a typical member of the fuscoaenea species-group. This group consists of eight previously known species (see Bengtsson 1991). S. tabelli is thus an interesting addition to this group because it is the first species which has been found only from Asia. All other known species in the group have been recorded also from the central and southern Europe (see also Bengtsson 1997b).

Acknowledgements. My special thanks are due to Mr. Bengt Åke Bengtsson (Färjestaden, Sweden) for his support at the determination of the material and viewpoints at the manuscript. My thanks are also due to Mr. Bo Wikström (Nummela, Finland) and Mr. Kimmo Silvonen (Espoo, Finland) who kindly helped me with processing the photographs. Finally I thank Jukka Tabell (Hartola, Finland) who has been my companion during the expedition.

\section{References}

Bengtsson, B. Å. 1991: Review of the fuscoaenea speciesgroup of Scythris (Lepidoptera: Sythrididae). Entomologica Scandinavica 21: 405-414.

Bengtsson, B. Å. 1997a: Notes on interesting scythridids in the Zoological Museum, Helsinki, Finland (Lepidoptera, Scythrididae). — Entomologica Fennica 8: 89102.

Bengtsson, B. Å. 1997b: Scythrididae. — In: Huemer, P., Karsholt, O. \& Lyneborg, L. (eds.), Microlepidoptera of Europe 2: 1-301.

Nupponen, K., Bengtsson, B. Å., Kaitila, J.-P., Nupponen, T., Junnilainen, J. \& Olschwang, V. 2000: The scythridid fauna of the southern Ural Mountains, with description of fourteen new species (Lepidoptera: Scythrididae). - Entomologica Fennica 11: 5-34.

Staudinger, O. 1880: Lepidopteren-Fauna Kleinasiens. Horae Societatis Entomologicae Rossicae T.XV (1879) 15: $159-435$. 